\title{
Perjanjian Sewa Menyewa yang Dibuat di Hadapan Notaris Kaitannya dengan Putusan Hakim Mahkamah Agung
}

\author{
Heru Guntoro \\ Fakultas Hukum Universitas 17 Agustus 1945 \\ Jl. Adisucipto No.26 Banyuwangi \\ heru.guntoro@ymail.com
}

\begin{abstract}
An agreement shall be binding upon the parties, and each party is obliged to be responsible for what is stated in the agreement. This research focuses on the legal perspective of a lease agreement made before a notary public and its relation to the decision of Supreme Court Justice. The study uses normative, philosophical, juridical analysis; in addition, it is a qualitative, comparative research. During the study, a library research is conducted and legal materials are analyzed qualitatively using a case approach. The research leads to a conclusion that, first, a lease agreement made before a notary public is legal and authentic, and second, the decision of Supreme Court strengthens the lease agreement made before a notary public, and the Notary Deed is validated and inviolable.
\end{abstract}

Key words : Lease agreement, notary deed, decision of supreme court

\begin{abstract}
Abstrak
Perjanjian itu bersifat mengikat para pihak dan masing-masing pihak harus bertanggung jawab terhadap apa yang telah disepakati dalam perjanjian tersebut. Penelitian ini mengangkat permasalahan bagaimana perspektif hukum perjanjian sewa menyewa yang dibuat di hadapan notaris dan kaitannya dengan putusan Hakim Mahkamah Agung. Untuk mengkaji permasalahan digunakan penelitian yuridis normatif - filosofis yang bersifat kualitatif dan komparatif. Penelitian yang dilakukan adalah penelitian kepustakaan, bahan-bahan hukum yang dianalisis secara kualitatif dengan pendekatan kasus. Dari penelitian yang dilakukan dapat disimpulkan bahwa: Pertama, perjanjian sewa menyewa yang dilakukan di hadapan Notaris merupakan suatu perjanjian yang sah dan otentik; Kedua, Putusan Mahkamah Agung menguatkan perjanjian sewa menyewa yang dilakukan di hadapan Notaris dan Akta Notaris diakui keabsahannya serta tidak bisa diganggu gugat.
\end{abstract}

Kata kunci : Perjanjian sewa menyewa, akta notaris, putusan mahkamah agung. 


\section{Pendahuluan}

Hukum secara tegas mengatur perbuatan-perbuatan manusia yang bersifat lahiriah, dan hukum mempunyai sifat untuk menciptakan keseimbangan antara kepentingan-kepentingan para warga masyarakat. Tugas pokok dari hukum adalah menciptakan ketertiban, oleh karena ketertiban merupakan syarat terpokok daripada adanya suatu masyarakat yang teratur, hal mana berlaku bagi masyarakat manusia di dalam segala bentuknya.

Pada dasarnya hukum di Indonesia dibedakan menjadi dua macam, yaitu hukum publik dan hukum privat (hukum perdata). Hukum publik merupakan ketentuan-ketentuan hukum yang mengatur kepentingan yang bersifat umum, sedangkan hukum perdata mengatur kepentingan yang bersifat keperdataan. Hukum perikatan termasuk dalam hukum perdata. Perikatan artinya hal yang mengikat antara orang yang satu dengan orang yang lain. Hal yang mengikat itu adalah peristiwa hukum yang dapat berupa perbuatan, misalnya jual beli, hutang piutang dapat berupa kejadian misalnya kelahiran, kematian, dapat berupa keadaan, misalnya pekarangan berdampingan, rumah bersusun.

Mengenai sumber-sumber perikatan, oleh undang-undang diterangkan bahwa suatu perikatan dapat lahir dari suatu persetujuan (perjanjian) atau dari undangundang. Perikatan yang lahir dari undang-undang dapat dibagi lagi atas perikatanperikatan yang lahir dari undang-undang saja dan yang lahir karena suatu perbuatan orang. Perikatan dapat dibagi lagi atas perikatan-perikatan yang lahir dari suatu perbuatan yang diperbolehkan dan yang lahir dari perbuatan yang berlawanan dengan hukum.

Sewa-menyewa merupakan suatu perjanjian dengan mana pihak yang satu mengikatkan dirinya untuk memberikan kepada pihak yang lainnya kenikmatan dari sesuatu barang, selama suatu waktu tertentu dan dengan pembayaran suatu harga yang oleh pihak yang tersebut terakhir itu disanggupi pembayarannya. Demikianlah definisi yang diberikan oleh Pasal 1548 BW mengenai perjanjian sewa-menyewa.

Menurut R. Subekti sewa-menyewa, seperti halnya jual-beli dan perjanjianperjanjian pada umumnya, adalah suatu perjanjian kontrak konsensual. Artinya, perjanjian tersebut sudah sah dan mengikat pada detik tercapainya sepakat mengenai unsur-unsur pokoknya, yaitu barang dan harga. ${ }^{1}$

${ }^{1}$ R. Subekti, Aneka Perjanjian, PT. Citra Aditya Bakti, Bandung, 1995, hlm. 39. 
Kewajiban pihak yang satu adalah menyerahkan barangnya untuk dinikmati oleh pihak yang lain, sedangkan kewajiban pihak yang terakhir ini adalah membayar "harga sewa". Jadi barang diserahkan tidak untuk dimiliki seperti halnya dalam jual-beli, tetapi hanya dipakai untuk dinikmati kegunaannya. Dengan demikian maka penyerahan hanya bersifat menyerahkan kekuasaan belaka atas barang yang disewa itu.

Kewajiban pihak yang menyewakan adalah barang untuk dinikmati dan bukannya menyerahkan barang hak milik atas barang tersebut. Dengan demikian maka seorang yang mempunyai hak nikmat-hasil dapat secara sah menyewakan barang yang dikuasainya dengan hak tersebut.

Menurut R.M. Sudikno Mertokusumo, ada beberapa macam bentuk perjanjian yaitu perjanjian bawah tangan yang ditandatangani oleh pihak yang bersangkutan saja, perjanjian dengan saksi notaris untuk melegalisir tanda tangan para pihak, dan perjanjian yang dibuat dihadapan dan oleh notaris dalam bentuk akta notaris. ${ }^{2}$

Akta notaris merupakan bukti prima facie mengenai fakta, yaitu pernyataan atau perjanjian yang termuat dalam akta notaris, mengingat notaris di Indonesia merupakan pejabat umum yang mempunyai kewenangan untuk memberikan kesaksian atau melegalisir suatu fakta. Jika isi dari fakta semacam itu disangkal disuatu pengadilan, maka pengadilan harus menghormati dan mengakui isi akta notariel, kecuali pihak yang menyangkal dapat membuktikan bahwa bagian tertentu dari akta telah diganti atau bahwa hal itu bukanlah yang disetujui oleh para pihak, pembuktian mana yang sangat berat.

Seperti yang terjadi di Pasar Kapuas Indah Pontianak dimana salah salah satu pihak yang melakukan perjanjian, membatalkan secara sepihak perjanjian yang telah disepakati bersama. Dalam Putusan Hakim Mahkamah Agung No. 210 PK/Pdt/ 2008 yang isi pokoknya adalah menolak permohonan kasasi dari para pemohon kasasi, menghukum para Pemohon kasasi untuk membayar biaya perkara dalam tingkat kasasi ini ditetapkan sebanyak Rp. 500.000,- ( lima ratus ribu rupiah ).

Berdasarkan ulasan singkat di atas jelaslah bahwa perjanjian itu bersifat mengikat para pihak dan masing - masing pihak harus bertanggung jawab terhadap apa yang telah disepakati dalam perjanjian tersebut, oleh karena itu dalam pelaksanaannya masing-masing pihak harus memperhatikan koridor hukum baik hak maupun kewajiban yang telah disepakati dalam perjanjian tersebut.

${ }^{2}$ Sudikno Mertokusumo, Pengantar Hukum Perdata Tertulis (BW), Sinar Grafika, Yogyakarta, 2001, hlm. 166. 


\section{Rumusan Masalah}

Berdasarkan uraian dalam latar belakang di atas maka dapat diberikan rumusan masalah sebagai berikut: Pertama, bagaimana perspektif hukum perjanjian sewamenyewa pengelolaan lingkungan komplek pasar menurut KUH Perdata? Kedua, bagaimana Putusan Hakim Mahkamah Agung No. 210 PK/Pdt/2008 dalam kaitannya dengan perjanjian sewa-menyewa di Pasar Kapuas Indah Pontianak?

\section{Tujuan Penelitian}

Tujuan dari penelitian ini adalah: pertama, untuk mengetahui dan menganalisis perspektif hukum perjanjian sewa-menyewa pengelolaan lingkungan kompleks pasar menurut KUH Perdata. Kedua, untuk mengetahui bagaimana Putusan Hakim Mahkamah Agung No. 210 PK/Pdt/2008 dalam kaitannya dengan perjanjian sewamenyewa di Pasar Kapuas Indah Pontianak.

\section{Metode Penelitian}

Dalam penelitian ini pendekatan yang dipakai adalah pendekatan yuridis normatif. Dasar dipilihnya pendekatan kasus (case apporach) ini karena dilakukan dengan cara melakukan kajian terhadap kasus yang berkaitan dengan permasalahan yang dihadapi dan yang telah manjadi putusan pengadilan yang memiliki kekuatan hukum tetap. Putusan yang dipakai dalam penelitian ini adalah putusan Hakim Mahkamah Agung No. 210 PK/Pdt/2008, tentang pembatalan perjanjian sewamenyewa secara sepihak antara PD. Kapuas Indah pontianak dan Wali Kota Pontianak dengan Hariyanto, Direktur PT. Dinamika Pratama, yang dituangkan dalam Akta Perjanjian sewa-menyewa Nomor 43 yang dibuat tanggal 29 Desember 1998 di hadapan Notaris Suwanto.

Pendekatan perundang-undangan (statute approach), yaitu pendekatan yang dilakukan dengan menelaah undang-undang dan regulasi yang berkaitan dengan upaya penyelesaian sengketa perjanjian sewa-menyewa menurut KUH Perdata. Penelitian hukum normatif ini bersumber dari bahan hukum primer yaitu merupakan bahan hukum yang terdapat dalam berbagai peraturan perundangundangan yang berkaitan dengan perjanjian sewa-menyewa yang dibuat dihadapan notaris. Bahan hukum primer yang digunakan sebagai acuan dalam penulisan ini 
adalah Kitab Undang-Undang Hukum Perdata dan Putusan Hakim Mahkamah Agung No.210 PK/Pdt/2008. Bahan hukum sekunder didapat dari literatur-literatur, brosur-brosur serta media massa sejenisnya yang secara langsung maupun tidak langsung dapat menunjang dalam penelitian ini sehingga dapat disajikan dan sekaligus dapat digunakan sebagai landasan teori. Kemudian dianalisis menggunakan metode deskriptif dan eksplanatif, yakni suatu metode yang bersifat memberikan keterangan, penjelasan dan untuk memperoleh gambaran secara singkat mengenai azas dan informasi untuk menyampaikan segala informasi dan bahan hukum yang telah diperoleh, kemudian menerapkannya menurut landasan hukum yang berlaku dari teori-teori yang ada.

\section{Hasil Penelitian dan Pembahasan}

\section{Perjanjian Sewa Menyewa Pengelolaan Lingkungan Kompleks Pasar menurut Kitab Undang-Undang Hukum Perdata}

Perjanjian merupakan perbuatan hukum yang dilakukan oleh dua orang atau lebih dimana dalam melaksanakan perbuatan hukum tersebut tidak semua orang cakap untuk melaksanakannya, akan tetapi dalam berbuat dan melaksanakan perjanjian tersebut seseorang atau badan hukum harus cakap menurut hukum. Perjanjian sewa menyewa pengelolaan Lingkungan Kompleks Pasar Indah Kapuas Pontianak yang dilakukan Kepala Pasar Indah Kapuas Pontianak dengan Direktur PT. Dinamika Pratama selaku pengelola lantai dasar.

R. Subekti merumuskan bahwa suatu perjanjian adalah suatu peristiwa dimana seorang berjanji kepada orang lain atau dimana dua orang itu saling berjanji untuk melaksanakan suatu hal. ${ }^{3}$ Dari peristiwa ini, timbulnya suatu hubungan antara dua orang tersebut dinamakan perikatan. Perjanjian itu menerbitkan suatu perikatan antara dua orang yang membuatnya. ${ }^{4}$

Sewa menyewa adalah suatu perjanjian dangan mana pihak yang satu mengikatkan dirinya untuk memberikan kepada pihak yang lain kenikmatan dari sesuatu barang, selama waktu tertentu dan dengan pembayarannya suatu harga yang oleh pihak yang terakhir tersebut disanggupi pembayarannya. Demikianlah

\footnotetext{
${ }^{3}$ R. Subekti, Pokok-pokok Hukum Perdata, PT. Intermasa, Jakarta, 1996, hlm. 89

${ }^{4}$ Bambang Waluyo, Sistem Pembuktian Dalam Peradilan Indonesia, Sinar Grafika, Jakarta, 1996, hlm. 44
} 
definisi yang diberikan oleh Pasal 1548 BW mengenai perjanjian sewa menyewa. Sewa menyewa sama halnya dengan jual beli dan perjanjian yang lain pada umumnya adalah suatu perjanjian konsensual. Artinya, sah dan mengikat pada detik tercapainya sepakat mengenai unsur-unsur pokoknya, yaitu barang dan harga.

Kalau seseorang diserahi suatu barang untuk dipakai tanpa kewajiban membayar sesuatu apapun, maka yang terjadi adalah suatu perjanjian pinjam pakai. Jika si pemakai barang itu diwajibkan membayar, maka bukan lagi pinjam-pakai yang terjadi tetapi sewa-menyewa. ${ }^{5}$ Perkataan "waktu tertentu" dalam uraian Pasal 1584 BW ada yang menafsirkan bahwa pembuat undang-undang memang memikirkan pada perjanjian sewa menyewa dimana waktu sewa ditentukan, misalnya untuk enam bulan atau dua tahun dan lain sebagainya.

Pihak yang menyewakan barang, mempunyai kewajiban: 1) menyerahkan barang yang disewakan kepada penyewa; 2) memelihara barang yang disewakan sedemikian hingga dapat dipakai untuk keperluan yang dimaksudkan; 3) memberikan kepada penyewa kenikmatan dari barang yang disewakan selama berlangsungnya persewaan.

Adapun risiko dalam sewa menyewa selalu berhubungan dengan adanya overmacht sebagaimana dalam perjanjian pada umumnya adalah kewajiban untuk memikul kerugian yang disebabkan oleh suatu peristiwa yang terjadi di salah satu pihak maka akibat dari keadaan memaksa (overmacht) adalah: 1) kreditur tidak dapat minta pemenuhan prestasi (pada overmacht sementara sampai berakhirnya keadaan overmacht); 2) umurnya kewajiban untuk mengganti kerugian (Pasal 1244 BW dan 1245 BW); 3) pihak lawan tidak perlu minta pemutusan perjanjian (Pasal 1266 BW tidak berlaku, putusan hakim tidak perlu);4) umurnya kewajiban untuk berprestasi dari pihak lawan.

Di dalam risiko sewa menyewa diatur dalam Pasal 1553 KUH Perdata dimana disebutkan bahwa jika barang yang terjadi di luar kesalahan salah satu pihak, maka perjanjian sewa menyewa gugur demi hukum. Dalam Pasal 1559 KUH Perdata tentang mengulang sewakan "dan" melepaskan sewanya" kepada pihak lain. Pengertian mengulang sewakan adalah penyewa bertindak sendiri sebagai pihak yang menyewa dalam suatu perjanjian sewa menyewa kepada kedua yang dilakukan oleh pihak ketiga. Sedangkan dalam melepaskan sewanya ia mengundurkan diri sebagai penyewa dan menyuruhnya sebagai penyewa yang baru jadi didalam pihak

${ }^{5}$ R. Subekti, Op.Cit., hlm. 40 
ketiga tersebut berhadapan dengan pihak yang menyewakan dan pihak yang menyewakan dapat dimintakan pembatalan perjanjian sewa menyewa dengan disertai pembayaran kerugian pada yang menyewa dan tidak dapat diwajibkan pada perjanjian ulang sewa dengan pihak tersebut.

\section{Syarat Sahnya Perjanjian}

Dalam Kitab Undang-Undang Hukum perdata Pasal 1320 telah disebutkan bahwa untuk sahnya suatu perjanjian diperlukan adanya syarat-syarat tertentu. Adapun syarat-syarat tersebut antara lain: 1) sepakat mereka mengikatkan dirinya; 2) kecakapan mereka untuk membuat perjanjian; 3) sesuatu hal tertentu; 4) suatu sebab yang halal.

Dua syarat yang pertama dinamakan syarat-syarat subjektif. Karena mengenai orang-orangnya atau subjeknya yang mengadakan perjanjian, sedangkan dua syarat yang terahir dinamakan syarat objektif karena berkaitan objek yang diperjanjikan.

Orang yang melakukan suatu perjanjian harus cakap menurut hukum. Pada asasnya, setiap orang yang sudah dewasa, sehat jasmani dan rohani tanpa ada paksaan atau tekanan dari pihak manapun yaitu cakap menurut hukum. Sedangkan Pasal 1330 KUH Perdata telah disebutkan orang-orang yang tidak cakap membuat suatu perjanjian adalah : 1) orang-orang yang belum dewasa;2) mereka yang ditaruh dibawah pengampuan; 3) orang-orang perempuan, dalam hal-hal yang ditetapkan oleh undang-undang, dan pada umumnya senua orang kepada siapa undangundang telah melarang membuat perjanjian-perjanjian tertentu.

Sebagai syarat ketiga disebutkan bahwa suatu perjanjian harus mengenai suatu hal tertentu, artinya apa yang diperjanjikan mengenai hak-hak dan kewajiban kedua belah pihak. Barang dan/atau objek yang disebutkan dalam perjanjian paling sedikit harus ditentukan jenisnya.Sebagai syarat yang terakhir ditetapkan sebagai syarat keempat untuk suatu perjanjian yang sah adanya suatu sebab yang halal. Dengan sebab ini dimaksudkan tidak ada lain dari isi perjanjian.

Syarat-syarat tersebut di atas apabila tidak dipenuhi semuanya atau salah satu syarat tidak terpenuhi akan membawa akibat hukum bagi para pihak, mengenai hal ini harus diadakan perbedaan antara syarat subjektif dan syarat objektif. Dalam hal syarat objektif tidak terpenuhi maka perjanjian itu batal demi hukum, artinya dari semula tidak pernah dilahirkan suatu perjanjian dan tidak pernah ada suatu perikatan. Sedangkan apabila syarat subjektif tidak terpenuhi maka perjanjian batal 
demi hukum, melainkan perjanjiannya dapat dibatalkan, artinya salah satu pihak mempunyai hak untuk meminta pembatalan perjanjian tersebut. Pihak yang dapat meminta pembatalan itu adalah yang memberikan kesepakatannya secara tidak bebas.

Subyek dan Objek Perjanjian Sewa Menyewa Lingkungan Pasar Indah Kapuas Pontianak

Dalam perjanjian sewa menyewa yang dibahas kali ini terdapat subjek dan objek perjanjian. Hal yang menjadi subjek dari perjanjian adalah orang atau badan hukum yang mempunyai hak dan kewajiban untuk menguasai atau menikmati dari benda yang disewa serta mempunyai hak untuk menerima pembayaran harga sewa dan berkewajiban untuk menyerahkan bendanya.

Dengan demikian dalam perjanjian sewa menyewa komplek Pasar Indah Kapuas yang menjadi subjek hukum yaitu: a) Direktur PT. Dinamika Pratama sebagai subyek penyewa; b) PD. Kapuas Pontianak dan Wali Kota sebagai subjek yang menyewakan kompleks Pasar Indah Kapuas.

Objek perjanjian di sini dapat diartikan sebagai kebalikan dari subjek yang dalam suatu perjanjian merupakan hal yang dapat diperlakukan oleh subjek tertentu berupa suatu hal yang penting bagi tujuan yang hendak dicapai dalam pembentukan perjanjian tersebut. Pada umumnya yang menjadi objek perjanjian adalah harta benda karena hukum perjanjian itu termasuk dalam ruang lingkup harta kekayaan. Dalam perjanjian sewa menyewa yang dilakukan kali ini yang menjadi objeknya adalah kompleks Pasar Indah Kapuas Pontianak lantai dasar.

\section{Sengketa Dalam Perjanjian Sewa Menyewa Akibat Wanprestasi}

Seperti kita ketahui bersama bahwa setiap saat dalam suatu perjanjian terletak kewajiban untuk memenuhi prestasi. Jika seseorang tidak melaksanakan kewajiban sebagaimana yang telah di perjanjikan maka dapat dikatakan bahwa orang tersebut melakukan wanprestasi atau ingkar janji. Wanprestasi ada beberapa macam bentuk, yakni: 1) tidak memenuhi prestasi sama sekali; 2) terlambat memenuhi prestasi; 3) memenuhi prestasi tetapi tidak secara baik.

Wanprestasi ini mempunyai akibat-akibat yang begitu penting. Oleh karena itu harus ditetapkan terlebih dahulu apakah salah satu pihak melakukan wanprestasi dan ini harus dibuktikan. Kadang-kadang tidak mudah untuk mengatakan bahwa 
seseorang lalai atau lupa. Karena seringkali tidak dijanjikan dengan tepat kapan suatu pihak diwajibkan memenuhi prestasi yang diperjanjikan.

Kemudian mengenai pembatalan perjanjian, hal ini bertujuan membawa kedua belah pihak kembali kepada sebelum perjanjian diadakan. Kalau satu pihak telah menerima sesuatu dari pihak lain, pihak uang maupun barang maka dikembalikan. Pembatalan perjanjian karena kelalaian atau wanprestasi ini diatur dalam Pasal 1266 KUH Perdata yang berbunyi: "Syarat batal dianggap selamanya dicantumkan dalam perjanjian yang timbal balik manakala salah satu pihak tidak memenuhi kewajiban. Dalam hal demikian perjanjian tidak batal demi hukum tetapi pembatalan harus dimintakan kepada hakim. Permintaan itu juga harus dilakukan meskipun syarat batal mengenai tidak dipenuhinya kewajiban itu dinyatakan dalam perjanjian. Jika syarat batal tidak dinyatakan dalam perjanjian, hakim leluasa menurut keadaan atas permintaan tergugat untuk memberikan suatu jangka waktu guna kesempatan memenuhi kewajibannya, jangka waktu mana tidak boleh dari satu bulan".

Adanya ketentuan pembatalan perjanjian, maka harus dimintakan kepada hakim. Menurut penulis tidaklah mungkin perjanjian itu batal secara otomatis pada waktu debitur itu nyata-nyata melalaikan kewajibannya karena hakim memiliki kekuasaan untuk menilai besar kecilnya kelalaian dibandingkan dengan besarnya akibat pembatalan perjanjian yang mungkin menimpa pihak yang dirugikan kalau hakim menimbang bahwa kelalaian salah satu pihak terlalu kecil dan tidak berarti sedangkan pembatalan perjanjian akan ditolak oleh atau membawa kerugian yang terlalu besar bagi pihak lain maka permohonan untuk pembatalan perjanjian akan ditolak hakim.

Pihak dirugikan dapat memilih antara berbagai kemungkinan antara lain: 1) Dapat meminta pelaksanaan perjanjian, meskipun pelaksanan ini sudah terlambat; 2) Dapat meminta penggantian kerugian saja, yaitu kerugian yang dideritanya, karena perjanjian tidak atau terlambat dilaksanakan, atau dilaksanakan, tetapi tidak sebagaimana mestinya; 3) Dapat menuntut pelaksanaan perjanjian disertai dengan penggantian kerugian yang dideritanya sebagai akibat terlambatnya pelaksanaan perjanjian; 4) Dalam suatu hal perjanjian yang meletakkan kewajiban timbal balik, kelalaian suatu pihak kepada pihak yang lain untuk meminta pada hakim supaya perjanjian dibatalkan, disertai dengan permintaan penggantian kerugian.

Hak ini diberikan oleh Pasal 1266 BW yang menentukan bahwa tiap perjanjian bilateral selalu dianggap telah dibuat dengan syarat, bahwa kelalaian salah satu 
pihak akan mengakibatkan pembatalan perjanjian. Pembatalan perjanjian tersebut harus dimintakan pada hakim. ${ }^{6}$

\section{Perbuatan Melawan Hukum Dalam Perjanjian Sewa Menyewa}

Perbuatan melawan hukum (onrechtmatige daad) adalah suatu perbuatan yang bertentangan dengan hak subjektif orang lain dan bertentangan dengan kewajiban hukum pelaku. Perbuatan melawan hukum diatur dalam Buku III Bab 3 Pasal 1365 KUH Perdata yang masuk kedalam perikatan-perikatan yang timbul demi undangundang. Pasal 1365 KUH Perdata berbunyi : "Tiap perbuatan melawan hukum, yang membawa kerugian kepada orang lain, mewajibkan orang yang karena kesalahannya menerbitkan kerugian itu, mengganti kerugian tersebut".

Menurut R. Setiawan, unsur-unsur dalam Pasal 1365 KUH Perdata adalah sebagai berikut: 1) perbuatan, yaitu terjadi karena tindakan dilaksanakan atau tidak seharusnya dilaksanakan; 2) melanggar hukum, yaitu terjadi karena adanya perkembangan masyarakat dalam menyesuaikan dengan keadaan pengertian melanggar, yaitu: a. hukum yang berlaku yang terdapat dalam perundangundangan; b. hubungan orang lain; 3) kesalahan, yaitu bahwa dari perbuatan melawan hukum merupakan perbuatan yang salah dan tidak dapat dibenarkan, unsur kesalahan dapat terjadi karena disengaja atau tidak disengaja; 4) kerugian, yaitu kerugian yang ditimbulkan oleh perbuatan melawan hukum. ${ }^{7}$

Dalam ilmu hukum dikenal 3 (tiga) kategori dari perbuatan melawan hukum, yaitu sebagai berikut: 1) perbuatan melawan hukum dengan kesengajaan; 2) perbuatan melawan hukum tanpa kesalahan (tanpa unsur kesengajaan atau kelalaian); 3) perbuatan melawan hukum karena kelalaian.

Setelah meninjau perumusan luas dari onrechtmetige daad, maka yang termasuk perbuatan melawan hukum adalah setiap tindakan : 1) bertentangan dengan hak orang lain; 2) bertentangan dengan kewajiban hukumnya sendiri; 3) bertentangan dengan kesusilaan; 4) bertentangan dengan keharusan yang harus diindahkan dalam pergaulan masyarakat mengenai orang lain atau benda.

\footnotetext{
${ }^{6}$ R. Subekti, Op.Cit., hlm. 148

${ }^{7}$ Rachmad Setiawan, Tinjauan Elementer Perbuatan Melanggar Hukum, Bina Cipta, Jakarta, 1991, hlm. 45
} 


\section{Putusan Hakim Mahkamah Agung Kaitannya dengan Perjanjian Sewa Menyewa}

Dalam lapangan perdata adanya campur tangan dari hakim timbul, apabila persoalannya diajukan oleh para pihak yang bersangkutan ke pengadilan. Pihak yang mengajukan gugatan ke pengadilan adalah mereka yang merasa diperlakukan tidak adil atau merasa haknya dilanggar oleh pihak lain dan disebut penggugat dan menarik orang lain yang pada pendapatnya melanggar haknya itu sebagai tergugat.

Dalam hal tanya jawab di muka pengadilan bagi para pihak yang berperkara bebas untuk mengemukakan peristiwa-peristiwa yang berlainan dengan perkaranya. Untuk itu hakim dalam pemeriksaan suatu perkara perdata di pengadilan harus mengetahui dasar-dasar dan alasan-alasan dari seorang penggugat maupun tergugat tentang pokok perkaranya, baik perkara yang diajukan oleh penggugat atau keterangan yang diberikan oleh tergugat. Pada dasarnya hakim di dalam mengambil keputusan tentang perkara yang diperiksanya harus terlebih dahulu dibuktikan dan apakah peristiwa itu sudah cukup bukti atau tidak, maka dalam hal ini hak menggunakan teori pembuktian guna dapat menerapkan hukum secara tepat, adil dan benar. Karena dari pemeriksaan alat bukti tersebut hakim akan dapat mengambil suatu kesimpulan, untuk itu hakim menentukan, apa yang harus dibuktikan dan pihak mana yang harus memberikan bukti, artinya hakim akan menentukan pihak mana (penggugat atau tergugat) akan memikul risiko tentang beban pembuktian dalam hal ini beban pembuktian tidak boleh berat sebelah. Sebagaimana yang diatur dalam Pasal 1866 BW yang menjelaskan tentang macam-macam alat bukti dalam perkara perdata yang terdiri dari: 1) bukti tertulis/surat; 2) bukti dengan saksisaksi; 3) persangkaan-persangkaan; 4) Pengakuan; 5) sumpah segala sesuatunya yang mengindahkan aturan-aturan yang ditetapkan.

\section{Kekuatan Hukum Perjanjian Sewa Menyewa yang Dibuat Dihadapan Notaris}

Seorang notaris diangkat oleh Menteri Kehakiman, mempunyai tugas dan wewenang membuat akta. Akta otentik adalah akta yang dibuat dan diresmikan dalam bentuk menurut hukum, oleh atau dihadapan penjabat-penjabat umum yang berwenang berbuat demikian itu di tempat dimana akta tersebut dibuat.

Notaris berasal dari kata latin notarius yang artinya orang yang membuat catatan. Berdasarkan Pasal 1 Peraturan Penjabatan Notaris dimana Notaris dijadikan sebagai penjabat umum yang satu-satunya berwenang untuk membuat akta otentik 
mengenai semua perbuatan, perjanjian dan penetapan yang diharuskan oleh suatu peraturan atau oleh yang berkepentingan dikehendaki untuk dinyatakan dalam suatu akta otentik, menjamin kepastian tanggalnya, menyimpan aktanya dan memberikan grosse, salinan dan kutipannya, semuanya sepanjang pembuatan akta itu oleh suatu peraturan umum tidak juga ditugaskan atau dikecualikan kepada penjabat atau orang lain.

Dari pengertian tersebut di atas, maka dapat diketahui bahwa tugas pokok notaris adalah membuat akta-akta otentik. Adapun akta otentik itu menurut Pasal 1870 KUH Perdata memberikan kepada pihak-pihak yang membuatnya suatu pembuktian mutlak.

Selain yang disebut dalam undang-undang di tugas notaris, antara lain: 1) mendaftarkan akta-akta/surat-surat di bawah tangan (syukken), melakukan; 2) pengesahan (waarmeking); 3) melegalisir tanda tangan; 4) membuat dan mengesahkan (waarmeking) salinan/turunan berbagai dokumen; 5) mengusahakan disahkannya badan-badan, seperti perseroan terbatas dan perkumpulan agar memperoleh persetujuan / pengesahan sebagai badan hukum dari Menteri Kehakiman; 6) membuat keterangan hak waris (di bawah tangan); 7) pekerjaan-pekerjaan lain yang bertalian dengan lapangan yuridis dan perpajakan, seperti urusan bea materai dan sebagainya. ${ }^{8}$ Dengan demikian dalam pembuatan akta, orang-orang atau para pihak sebelumnya harus ada persetujuan kehendak yang didahului dengan mengadakan perundingan.

Menurut Abdul Kadir Muhammad, yang dimaksud dengan persetujuan kehendak adalah: "Kesepakatan seia sekata antara pihak-pihak mengenai pokokpokok perjanjian yang dibuat. Pokok perjanjian itu berupa objek perjanjian dan syarat-syarat perjanjian. Apa yang dikehendaki oleh pihak yang satu dengan pihak yang lain sama-sama dikehendaki" ${ }^{9}$

\section{Syarat Akta Notaris Sebagai Akta Otentik}

Pasal 15 ayat (1) UUJN menegaskan bahwa salah satu kewenangan notaris, yaitu membuat akta secara umum dengan batasan sepanjang: a. tidak dikecualikan kepada pejabat lain yang ditetapkan oleh undang-undang; b. menyangkut akta yang harus dibuat atau berwenang membuat akta otentik mengenai semua perbuatan, perjanjian

\footnotetext{
${ }^{8}$ G.H.S. Lumbang Tobing, Peraturan Jabatan Notaris, Sinar Grafika, Jakarta, 1980, hlm. 237.

${ }^{9}$ R. Subekti, Pokok-pokok Hukum Perdata, PT. Intermasa, Jakarta, 1996, hlm. 89
} 
dan ketetapan yang diharuskan oleh aturan hukum atau dikehendaki oleh yang bersangkutan; c. mengenai subjek hukum (orang atau badan hukum) untuk kepentingan siapa akta itu akta itu dibuat atau dikehendaki oleh yang berkepentingan; d. berwenang mengenai tempat, dimana akta itu dibuat hal ini sesuai dengan tempat kedudukan dan wilayah jabatan notaris; e. mengenai waktu pembuatan akta, dalam hal ini notaris harus menjamin kepastian waktu menghadap para penghadap yang tercantum dalam akta.

Akta yang dibuat di hadapan atau oleh notaris berkedudukan sebagai akta otentik menurut bentuk dan tata cara yang ditetapkan dalam UUJN, hal ini sejalan dengan pendapat Philipus M. Hadjon, ${ }^{10}$ bahwa syarat akta otentik, yaitu: 1) di dalam bentuk yang ditentukan oleh undang-undang; 2) dibuat oleh dan di hadapan Pejabat umum.

Dikemukakan pula oleh Irawan Soerodjo, bahwa ada 3 (tiga) unsur esenselia agar terpenuhinya syarat formal suatu akta otentik,, ${ }^{11}$ yaitu: a. di dalam bentuk yang ditentukan oleh undang-undang; b. dibuat oleh dan dihadapan Pejabat umum; c. akta yang dibuat oleh atau di hadapan Pejabat umum yang berwenang untuk itu dan di tempat dimana akta itu dibuat.

Pasal 1868 BW merupakan sumber untuk otensitas akta notaris juga merupakan dasar legalitas eksistensi akta notaris, dengan syarat-syarat sebagai berikut: pertama, akta itu harus dibuat oleh (door) atau di hadapan (ten overstaan) seorang pejabat umum. Pasal 38 UUJN yang mengatur mengenai sifat dan bentuk akta tidak menentukan mengenai sifat akta. Dalam Pasal 1 angka 7 UUJN menentukan bahwa akta notaris adalah akta otentik yang dibuat oleh atau dihadapan notaris menurut bentuk dan tata cara yang ditetapkan dalam UUJN dan secara tersirat dalam Pasal 58 ayat 2 UUJN disebutkan bahwa notaris wajib membuat daftar akta dan mencatat oleh atau di hadapan notaris. Dalam tataran hukum (kenotariatan) yang benar mengenai akta notaris dan notaris, jika suatu akta notaris dipermasalahkan oleh para pihak: a) para pihak datang kembali ke notaris untuk membuat akta pembatalan atas akta tersebut, dan dengan demikian akta yang dibatalkan sudah tidak mengikat lagi para pihak dan para pihak menanggung segala akibat dari pembatalan tersebut; b) jika para pihak tidak sepakat akta yang bersangkutan untuk dibatalkan, salah satu pihak dapat menggugat pihak lainnya, dengan gugatan untuk mendegradasikan akta

\footnotetext{
${ }^{10}$ Philipus M. Hadjon, Formulir Pendaftaran Tanah Bukan Akta Otentik, Surabaya Post, 31 Januari 2001, hlm. 3.

${ }^{11}$ Irawan Soerodjo, Kepastian Hukum Hak. Atas Tanah Di Indonesia, Arkola, Surabaya, 2003, hlm. 148.
} 
notaris menjadi akta di bawah tangan. Setelah didegradasikan, maka hakim yang memeriksa gugatan dapat memberikan penafsiran tersendiri atas akta notaris yang sudah terdegradasikan, apakah tetap mengikat para pihak atau dibatalkan. Hal ini tergantung pembuktian dan penilaian hakim. Kedua, akta itu harus dibuat dalam dalam bentuk yang ditentukan oleh undang-undang. Ketika kepada para notaris masih diberlakukan Peraturan Jabatan Notaris (PJN), masih diragukan apakah akta yang dibuat sesuai dengan undan-undang? Pengaturan pertama kali notaris Indonesia berdasarkan Instruktie voor de Notarissen Residerende in Nederlands Indie dengan Stbl. No. 11, tanggal 7 Maret 1822,,2 kemudian dengan Reglement op Het Notaris Ambt in Indonesia (Stb.1860:3), dan Reglement ini berasal dari Wet op Het Notarisambt (1842), kemudian Reglement tersebut diterjemahkan menjadi PJN. ${ }^{13}$ Pejabat Umum oleholeh di hadapan siapa akta itu dibuat harus mempunyai wewenang untuk membuat akta tersebut.

Wewenang notaris ada empat hal, yaitu : a) notaris harus berwenang sepanjang yang menyangkut akta yang harus dibuat itu; b) notaris harus berwenang sepanjang mengenai orang-orang untuk kepentingan siapa akta itu dibuat; c) notaris harus berwenang sepanjang mengenai tempat, dimana akta itu dibuat; d) notaris harus berwenang sepanjang mengenai waktu pembuatan akta itu.

Akta notaris sebagai akta otentik mempunyai kekuatan nilai pembuktian: ${ }^{14} 1$ ) lahiriah (uitwendige bewijskraccht), nilai pembuktian akta notaris dari aspek lahiriah akta tersebut harus dilihat apa adanya bukan ada apa. Secara lahiriah tidak perlu dipertentangkan dengan alat bukti yang lainnya. Jika ada yang menilai bahwa suatu akta notaris tidak memenuhi syarat sebagai akta, maka yang bersangkutan wajib membuktikan bahwa akta tersebut secara lahiriah bukan akta otentik; 2) formal (formele bewijskracht), akta notaris harus memberikan kepastian bahwa sesuatu kejadian dan fakta tersebut dalam akta betul-betul dilakukan oleh notaris atau diterangkan oleh pihak-pihak yang menghadap pada saat tercantum dalam akta sesuai dengan prosedur yang sudah ditentukan dalam pembutan akta. Secara formal untuk membuktikan kebenaran dan kepastian tentang hari, tanggal, bulan, tahun, pukul (waktu) menghadap, dan para pihak yang menghadap, paraf dan tanda tangan para pihak/penghadap, saksi dan notaris (pada akta pejabat/berita acara), dan

\footnotetext{
${ }^{12}$ R. Soegondo Notodisoerjo, Op.Cit., hlm. 24-25.

${ }^{13}$ Tan Thong Kie, Op. Cit., hlm. 362.

${ }^{14}$ R. Soegondo Notodisoerjo, Op. Cit., hlm. 55. Lumban Tobing, Op.Cit., hlm. 54-65.
} 
mencatatkan keterangan atau pernyataan para pihak penghadap (pada akta pihak); 3) materiil (materiele bewijskracht), merupakan kepastian tentang materi suatu akta, bahwa apa yang tersebut dalam akta merupakan pembuktian yang sah terhadap pihak-pihak yang membuat akta atau mereka yang mendapat hak dan berlaku untuk umum, kecuali ada pembuktian sebaliknya (tegenbewijs). Keterangan atau pernyataan yang dituangkan/dimuat dalam Akta Pejabat atau keterangan atau para pihak yang diberikan atau disampaikan di hadapan notaris (akta pihak) dan para pihak harus dinilai benar berkata yang kemudian dituangkan atau dimuat dalam akta berlaku sebagai yang benar atau setiap orang yang datang menghadap notaris yang kemudian keterangannya dituangkan dimuat dalam akta harus dinilai telah benar berkata.

Ketiga aspek tersebut di atas merupakan kesempurnaan akta notaris sebagai akta otentik dan siapapun terikat oleh akta tersebut. Jika dapat dibuktikan dalam suatu persidangan pengadilan bahwa ada salah satu aspek tersebut tidak benar, maka akta yang bersangkutan hanya mempunyai kekuatan pembuktian sebagai akta di bawah tangan atau akta tersebut didegradasikan kekuatan pembuktiannya sebagai akta yang mempunyai kekuatan pembuktian sebagai akta bawah tangan.

Aspek lahiriah dari akta notaris dalam yurisprudensi Mahkamah Agung bahwa akta notaris sebagai alat bukti berkaitan dengan tugas pelaksanaan tugas notaris, contohnya Putusan Mahkamah Agung Republik Indonesia Nomor 210 PK/ Pdt/2008, yang menegaskan bahwa judex factie dalam amar putusannya membatalkan akta notaris, hal ini tidak dapat dibenarkan, karena Pejabat Notaris fungsinya hanya mencatatkan (menuliskan) apa-apa yang dikehendaki dan dikemukakan oleh para pihak yang menghadap notaris tersebut. Tidak ada kewajiban bagi notaris untuk menyelidiki secara materil apa-apa (hal-hal) yang dikemukakan oleh penghadap notaris tersebut.

Berdasarkan pada putusan Mahkamah Agung tersebut dapat disimpulkan bahwa: 1) akta notaris tidak dapat dibatalkan; 2) fungsi notaris hanya mencatatkan (menuliskan) apa saja yang dikehendaki dan dikemukakan oleh para pihak yang menghadap notaris tersebut; 3) tidak ada kewajiban bagi notaris untuk menyelidiki secara materil apa saja yang dikemukakan oleh penghadap tersebut.

\section{Penutup}

Setelah dijelaskan secara panjang lebar masalah pelaksanaan perjanjian sewa menyewa kompleks Pasar Indah Kapuas Pontianak, maka dapat ditarik kesimpulan 
sebagai berikut: Pertama, perjanjian sewa menyewa yang dilakukan di hadapan Notaris merupakan suatu perjanjian yang sah dan otentik; Kedua, Putusan Mahkamah Agung menguatkan perjanjian sewa menyewa yang dilakukan di hadapan notaris dan akta notaris diakui keabsahannya serta tidak bisa diganggu gugat.

Perjanjian yang telah disepakati kedua belah pihak hendaknya dihargai sebagai kesepakatan bersama yang memiliki kekuatan hukum yang mengikat antara para pihak yang melakukan perjanjian. Setiap perjanjian yang akan disepakati sebaiknya dibuat di hadapan notaris agar memiliki kekuatan hukum, apabila terjadi hal-hal yang tidak diinginkan dan sampai di sidang di pengadilan ada bukti yang otentik dan tidak bisa dibatalkan.

\section{Daftar Pustaka}

Lumbang Tobing, G.H.S., Peraturan Jabatan Notaris, Sinar Grafika, Jakarta, 1980.

M. Hadjon, Philipus, Formulir Pendaftaran Tanah Bukan Akta Otentik, Surabaya Post, 31 Januari 2001.

Mertokusumo, Sudikno, Pengantar Hukum Perdata Tertulis (BW), Sinar Grafika, Yogyakarta, 2001.

Setiawan, Rachmad, Tinjauan Elementer Perbuatan Melanggar Hukum, Bina Cipta, Jakarta, 1991.

Soerodjo Irawan, Kepastian Hukum Hak Atas Tanah Di Indonesia, Arkola, Surabaya, 2003.

Subekti, R., Aneka Perjanjian, PT. Citra Aditya Bakti, Bandung, 1995. , Pokok-pokok Hukum Perdata, PT. Intermasa, Jakarta, 1996.

Waluyo, Bambang, Sistem Pembuktian Dalam Peradilan Indonesia, Sinar Grafika, Jakarta, 1996. 